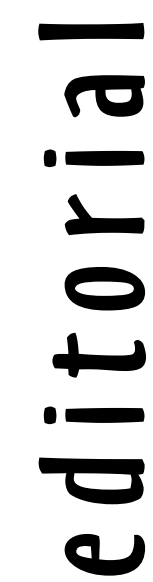

O presente número da revista Aletria demonstra, de modo estimulante, a complexidade e a natureza multifária da noção de espaço. Na diversidade e na riqueza dos artigos apresentados, o foco é, naturalmente, o texto literário. Contudo, a partir de tal foco se exploram não apenas aspectos propriamente estéticos vinculados ao termo espaço, mas também aspectos históricos, científicos, filosóficos, políticos, semiológicos. São muitas as acepções do termo, com freqüência conflituosas, como as que definem espaço como objetivo ou subjetivo, natural ou humano, concreto ou abstrato, sensível ou inteligível, material ou ideal, dado observável ou condição de possibilidade, empírico ou simbólico, determinado ou determinante, relacional ou absoluto. Apesar de desconcertante, ou justamente por sê-lo, o caráter conflituoso é também altamente produtivo como contribuição aos Estudos Literários, seja pelas diversas possibilidades analíticas abertas, pelos debates inescapavelmente teóricos suscitados, seja ainda pelo estímulo a experiências escriturais, as quais se valem, como ponto de partida, da liberdade do gênero ensaio. Nos vinte e um trabalhos aqui expostos, com significativa força se revela essa provocativa combinação - em diferentes arranjos - de teoria, análise e escrita literárias.

O volume é divido em cinco seções, antecedidas por um texto que atua como espécie de dínamo de conceitos e imagens. No artigo de Hans Ulrich Gumbrecht, descreve-se, na referência aos estádios esportivos, a dinâmica que coloca em interação aspectos associados a espaços investidos da função de encantamento (pode-se sugerir que aí se inclua o espaço literário): autonomia em relação aos espaços cotidianos; alternância de momentos "vazios" e "plenos"; promessas de epifanias existenciais e formais; experiência da temporalidade; gestação de um corpo comunal, simultaneamente público e individualizado; acesso à percepção por intensidades, e não por representações, a qual emerge do interior da consciência racional e secularizada.

Na seção Topografias da linguagem, está em jogo a pertinência de se atribuir à linguagem verbal algum sentido de espacialidade. Tal atribuição pode ocorrer mediante a noção, fundamental no pensamento de Gaston Bachelard, de imagem, a qual conjuga dialeticamente as funções material e arquetípica, a exterioridade e a subjetividade do espaço; pode também se valer da demonstração de que há obras literárias que buscam homologias entre o espaço 
extratextual e o textual, entre o mundo observado e a escrita, a partir da similaridade de suas conformações; pode, ainda, propor uma espécie de homologia às avessas, ao se conceber o texto literário como "lugar em crise".

Em Imaginários urbanos, se entrecruzam abordagens de textos sobre cidades e de cidades como texto. A ressonância mais forte é, sem dúvida, a obra de Walter Benjamin. A flânerie soa pertinente ao Rio de Janeiro de Machado de Assis ou, repaginada por um senso de presente temporalmente distante, à Santiago de escritores chilenos contemporâneos, ou ainda ao trânsito do arquiteto por paisagens oníricas, estranhamente familiares. Entretanto, em outros cenários literários, a liberdade de deambulação se vê cerceada por mecanismos de interdição, por fronteiras territoriais, políticas, culturais e de outras ordens, como na Alemanha dividida e nas periferias das grandes metrópoles brasileiras.

A tópica do exílio e suas variações definem os artigos agrupados sob a rubrica (Não-) lugares. Nas negociações entre identidade e espaço, as migrações, as diásporas, a condição nômade podem ser observadas, em nível micro, quando o indivíduo expõe, no mundo e no texto intercambiáveis, sua "pele estrangeira"; em nível macro, quando se deflagra o conflito entre grandes culturas, como as que se vinculam a cristianismo, judaísmo e islamismo; ou entre vetores históricos, como os que contrapõem arcaico e moderno, centro e periferia, selvagem e racional, sertanejo e republicano.

Em Ficções: deslocamentos, as abordagens de inspiração espacial se diversificam. Têm em comum a reflexão sobre os parâmetros do que se entende por literatura moderna, mas apontam para rumos pouco trilhados: da noção de atopia deriva a discussão sobre os limites dos sistemas de classificação; ao atrito entre visibilidade e invisibilidade se vincula o confronto entre espaços utópicos e distópicos; o tema da queda sinaliza a feição preponderantemente disfórica da modernidade; a literatura se oferece como ponto de partida para aportes relativos ao meio ambiente.

O debate teórico atinge explicitação completa na última seção, Teorias do espaço. Um gesto duplo busca, por um lado, rastrear os modos consolidados, e amplamente difundidos, de se lidar com a categoria espaço, tanto em termos gerais, a partir da apresentação de alguns sistemas filosóficos definidores do pensamento moderno, quanto em termos específicos, lançando-se luz sobre como determinados métodos de leitura do texto literário fizeram uso da noção de espaço. Por outro lado, busca também apresentar e inquirir vertentes que, colocando sob questionamento as referidas tradições teóricas, e defendendo a radicalidade especulativa, pretendem dotar o espaço literário de uma potência teórica inusitada.

No conjunto, os artigos deste número da Aletria constituem provas sedutoras de que uma investigação consistente sobre a literatura moderna ou, se se preferir, sobre as linhas mestras das "poéticas da modernidade" - não pode prescindir do debate quanto aos vínculos, diversificados mas recorrentes, entre texto literário e espaço. 


\section{THE HUNTING OF THE SNARK}

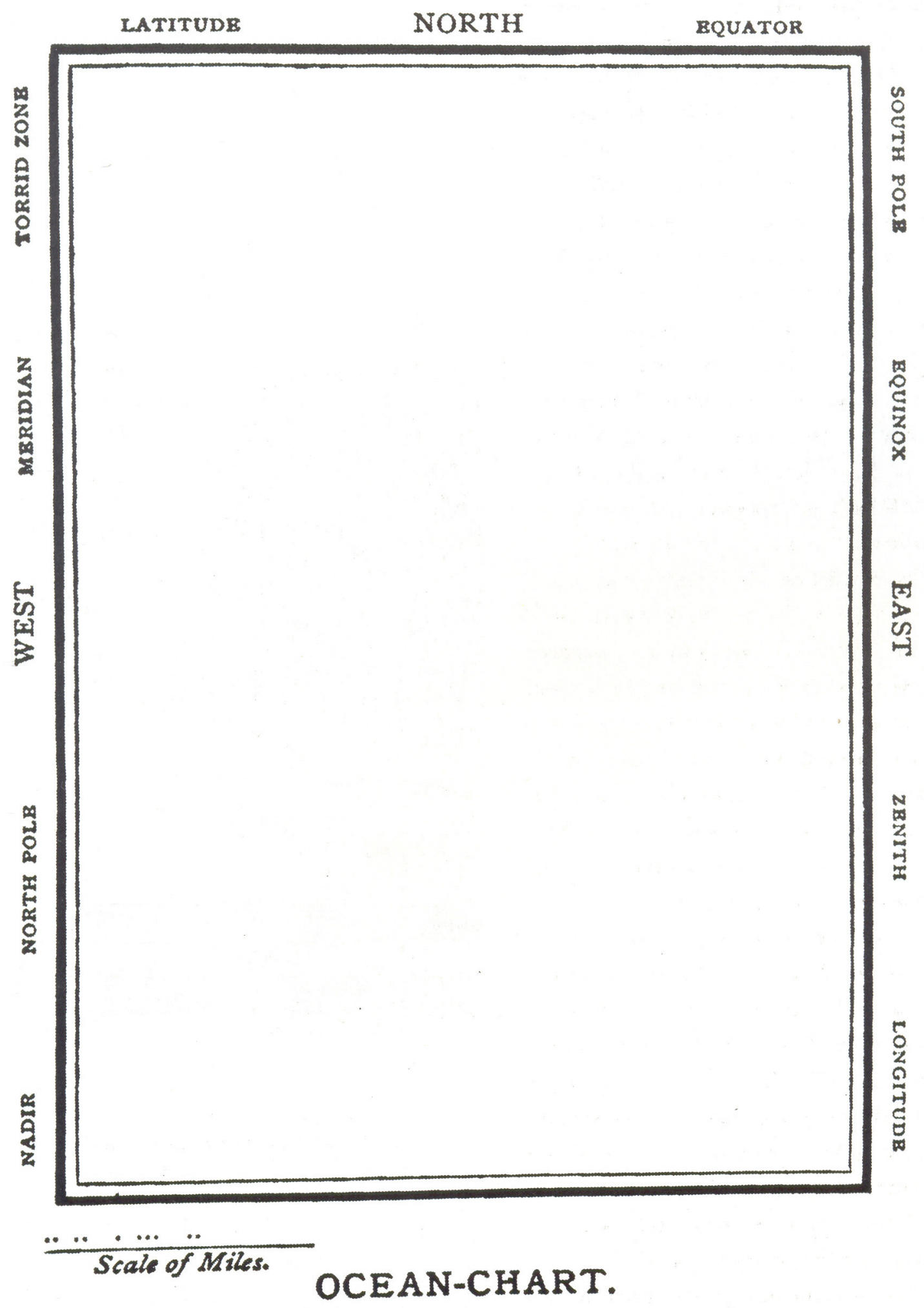


"Other maps are such shapes, with their islands and capes! But we've got our brave Captain to thank:"

(So the crew would protest) "that he's bought us the best A perfect and absolute blank!"

Lewis Carroll, The hunting of the snark 